\title{
Cultural Diversity as a Source of Conflict in the Focus of Non-Governmental and International Organizations: Bosnian Case Study
}

\author{
Justyna Pilarska \\ University of Wroclaw \\ email: justine_p@op.pl
}

\begin{abstract}
The article tackles the issue of cultural diversity as a phenomenon present in many multicultural communities that encompass representatives of different ethnic, national or religious traditions. Bosnia-Herzegovina provides an example of one of such communities, subject to analysis within the framework of this paper. The author firstly concentrates on the issues related to terminology of "cultural diversity" and "non-governmental organization", their specificity and interpretations. Then, an Introduction to Bosnian multiculturalism is made, displaying its local features, followed by a presentation of various NGO's activities with reference to Bosnian war and its aftermath. The focus is on the regional organizations that make the effort to reconstruct the multicultural bond, revealing its educational potential. The final analysis considers intercultural aspects of such approach to cultural differences that can become a point of reference in educational projects oriented at cross-cultural learning and intercultural dialogue. The latter, in turn, could contribute to the process of shaping constructive attitudes to representatives of the culturally diverse traditions.
\end{abstract}

Keywords: cultural diversity, NGOs, war in Bosnia, civic society,

\section{Introduction}

Since market and social institutions have for years been an integral part of the systems of the social policy in high-developed countries, both state and self-government public sector bodies do not constitute nowadays the sole entities of the social policy, as nongovernmental organizations are fundamental organizational form of pro bono activities, established in accordance with the idea of the civil society, and constituted by entities, which are usually international nonprofits.

They work in an independent and autonomous manner, nonetheless complementing given activities of governments for the benefit of constituencies in a civil society. Various NOGs encompass with their range of actions diverse goals and objectives as well as differentiated modus operandi from lobbying and advocacy to operations and project-oriented organizations, contributing to various services and humanitarian functions, advocating and monitoring policies. As a group of voluntary citizens organized on a local, national or international level, NGOs also encourage political participation through provision of information, organized around specific issues, such as human rights, environment, social equality, access to education, democratic rule, economic growth, or health. Thus, they provide analysis and expertise, serve as early warning mechanisms and help monitor and/or implement international agreements (definition of NGOs, retrieved online). They can also respond to number of social issues within given communities, including some aspects of culturally diverse environments such as access to education, equal rights, recognition of the status of ethnic minorities, etc.

Therefore, a non-governmental organization is a type of an organization that fulfils its role outlined by the discourse of social policy and philosophy of the civil society. Independent from the government, deprived of the profit motive and with the status of a public utility organization, NGOs address their effort at health care, widely understood social welfare, charity activities or education, in other words, focusing on acting for the public good. 
Active civil society is constituted by autonomous individuals, whose identity is shaped by the mechanism opposite to which Erich Fromm described as the "escape from freedom" (Fromm, 2011), they participate in the public life as they are conscious that satisfying their personal needs is not possible without agreement, cooperation and community with others, hence the readiness to participate in the problem solving concerning the widely-perceived social life. However, the latter issue encompasses not only internal problems of a given state structure, but embraces within its reach global social issues.

The members of a civic society are involved and participate in the process of shaping mechanisms that regulate the functioning of the social and economic life. Thus, although they are not the citizens of the ancient polis, one of the main tasks they are driven by, as Aristotle implied, is the good of the communities. Such welfare is, however, understood within the framework of a global meaning of the community of all individuals irrespective of their origin, race or faith. All things considered, such activities are devoted to the idea of egalitarianism.

If the members of communities formed according to such philosophy, convinced of the significance of solidarity and overall recognition for individuals to their self-determination, they act for the sake of counteracting destructive forms of crosscultural interactions, perceiving such potential of a community in a global frame, i. e. as the welfare of all citizens. Therefore, it is not exclusively limited to a given state or communities, such as the European Union.

The above does not imply altruism is the necessary condition of the functioning of the civic society, so the civic society does not carry the burden of the community of "unselfish saints" (Putnam, 1995), but can establish a community of conscious citizens caring about own interest, but at the same time comprehending that the action for the sake of the community in general can constitute a useful manner of achieving given global social or cultural goals. Having had instilled specific ideas and social values upon the processes of socialization, education and the upbringing, the individual is potentially able to commit own self to problems not directly concerning own reference group, yet s/he makes it driven by values appropriately internalized, and favourable for such actions. Non-governmental organization is therefore a socially oriented formation, dealing with problems in the name of public interest and tackling problems or substantial issues, also from the perspective of cultural diversity, that is the topic of interest within this article.

The reflections concern the activities of some local NGOs in Bosnia-Herzegovina, as well as some global agencies and documents that empower and strengthen the concept of culturally diversity. Since the latter, as the history of the fall of Yugoslavia proved (cf. Ramet, 2005), is often exposed to various destructive, separatist and nationalistic powers, it is of paramount importance for all the educationist, pedagogues and teachers working in a cross-cultural environment to become aware of the potential of cultural diversity, as well as its fragility to various political powers. If the second instance takes place, however, there are number of ways to counteract and balance such negative impact, hence selected examples of NGOs that run various inspiring education, artistic and academic projects are described. They prove that, cultural diversity is a source of inspiration for inter-religious, inter-ethnic and cross-national experiences that enrich the social world and human capital, yet on the other that it can be also a source of various antagonisms and conflicts, which resolutions require an active involvement (civic attitude) from the members of such a community as the example of the Pontanima interreligious choir, or the Institute for Strengthening Democracy in Bosnia And Herzegovina, Democracy and Human Rights in Multiethnic Societies prove. They acknowledgethat such initiatives can significantly contribute to the process of reconstructing the civil society as well as to shaping intercultural skills and competencies such as tolerance of ambiguity, cognitive curiosity and openness, behavioural flexibility, communicative awareness, recognition and respect for otherness and diversity, knowledge discovery and non-conventional way of perceiving the social and cultural reality, followed by empathy and ability to cooperate.

\section{International agencies and selected acts protecting cultural diversity}

Similarly as some non-governmental organizations, European Union undertakes activities for the sake of the peaceful coexistence of a culturally diverse societies, applying given polices towards ethnic and national minorities. The EU comprehensive approach within Bosnia-Herzegovina focuses on aspects such as defence, security, development and diplomacy, reforming state level institutions, and supporting Bosnia-Herzegovina to make economic progress. The Thessaloniki Declaration confirmed that the future of the Western Balkans is within the EU (The Thessaloniki Agenda for the Western Balkans), whereas The Stabilization and Association Agreement (SAA) is the framework for the European integration of Bosnia-Herzegovina, as entered into force on the 1 June 2015. Moreover, EUFOR also plays a big part in the 
comprehensive approach assisting in creating the conditions to deliver the long term political objective of a stable, viable, peaceful and multiethnic Bosnia-Herzegovina. As it can be read from the official policy of EUFOR "the operation reinforces the EU's comprehensive approach towards $\mathrm{BIH}$, and supports BIH's progress towards EU integration by its own efforts. The operation is part of the overall European Security and Defense Policy (ESDP) mission in BIH and of a closely coordinated EU presence in BIH. The EU Special Representative promotes overall EU political co-ordination in BIH. EU Commanders co-ordinate closely with the EUSR in BIH with a view to ensuring consistency of the EU military operation with the broader context of the EU activities in BIH". (Political/Military Background of ALTHEA, retrieved online).

International instruments and standards of the protection to the minorities rights are also a coherent part of the process of empowering a peaceful coexistence of the culturally diverse communities. It is estimated that the countries of OECD encompass over 50 national and ethnic minorities, i. e. generally concerning cultural minorities (Rabczuk, 2002). The international instruments are additionally enhanced by international linguistic and educational standards that empower egalitarian dimension of the social functioning of those culturally diverse whit the framework of the UNESCO Convention against Discrimination in Education, The Framework Convention for the Protection of National Minorities, or the European Charter for Regional or Minority Languages.

Another form reflecting the global interest in the cultural diversity, its strengthening as well as protection is the European Social Fund, i. e. one of the oldest structural funds and Europe's main tool for promoting employment and social inclusion. Its objective is to support various programmes and projects related to the social aspect of integration by disposal of resources favouring the adaptation of national economies of the membership countries of the EU. Thus, European social fund finances activities that aim at solving the key social issues such as ethnic, religious or national discrimination, all related to cultural diversity, that can be subject to unemployment or inequalities on the job market (Art 147 ex 124 TWE). The fund concentrates on the needs of the citizens of the membership countries, whereas its main objectives can divided into five domains, of out which one is particularly important in the context of cultural diversity, i. e. prevention from the social exclusion. Activities within this range encompass the groups of people who are subject to or threatened by exclusion, entailing physically and mentally disabled, immigrants, refuges, as well as cultural, religious or ethnic minorities.

As for international documents and bodies of the United Nations concerning human rights, thus consequently encompassing the recognition and protection of the cultural diversity, the following make a point of reference:

The International Convention on the Elimination of All Forms of Racial Discrimination (ICERD) As a third-generation human rights instrument, the Convention commits its members to the elimination of racial discrimination and the promotion of understanding among all races. Article 7 obliges parties to adopt "immediate and effective measures", particularly in education, to combat racial prejudice and encourage understanding and tolerance between different racial, ethnic and national groups (ICERD, Article 7).

The Convention against Torture and Other Cruel, Inhuman or Degrading Treatment or Punishment (commonly known as the United Nations Convention against Torture) is an international human rights treaty, that aims to prevent torture and other acts of cruel, inhuman, or degrading treatment or punishment around the world.

Convention on the Rights of the Child Adopted and opened for signature, ratification and accession by General Assembly resolution 44/25 of 20 November 1989 is a human rights treaty which sets out the civil, political, economic, social, health and cultural rights of children.

A Human Rights Commission, also known as a human relations commission, is a body set up to investigate, promote or protect human rights.

The Convention on the Protection and Promotion of the Diversity of Cultural Expressions, adopted under the auspices of the United Nations Educational, Cultural and Scientific Organization (UNESCO) in 2005, entered into force on 18 March 2007.

\section{Cultural diversity}


"Cultural diversity" has become one of the new hallmarks in international policy and law-making, becoming increasingly applied in various contexts, often correlated to the "exception culturelle" or, as a generic concept, opposed to the negative effects of economic globalisation (Burri-Nenova, 2009). Cultural diversity can be defined in a broad meaning as a coexistence in a given place and time of many different patterns of culture. Hence, the domain of a cultural diversity entails the language, confession, tradition influencing dress codes, ways of living, or customs related to the everyday life. Moreover, cultural diversity noticeably concerns a distinct set of policy objectives at the international level within the framework of various agencies or NGOs.

Due to the rapid growth of multicultural societies, intense migration flows and cross-cultural interspersion of the economic, social and political areas, including the accelerated development of digital technologies, cultural diversity is becoming a global fact. Thus, in its latest report on the protection and the promotion of the diversity of cultural expressions, the European Commission stresses the fact that "The diversity of cultural expressions lies at the heart of the European project" (Commission Report to the European Parliament, the Council, the European Economic and Social Committee and the Committee of the Regions on the Implementation of the European Agenda for Culture, SWD/2012/129 final). Challenges and other issues resulting from cultural diversity require by its very nature international cooperation and exchange of experiences regarding, for instance, multicultural education, equity pedagogy, human rights education, democracy training, cross-cultural communication schemes, reduction of prejudices concerning gender, social class, age, disability, religion, sexuality, race or/and ethnicity, language, beliefs, and etc. The latter process, i. e. reducing prejudices, may take place by developing positive attitudes towards different racial, ethnic and cultural groups in order to shape cooperative rather than competitive cross-cultural relations, empowering constructive cross-cultural experiences, as the experiences from the Bosnian case studies indicate.

Taking the above into account, cultural diversity is contemporarily perceived not only through the prism of the join heritage of mankind, that is to be preserved, protected and promoted, but can be also considered as a resource, requiring appropriate manner of management for the sake of establishing lasting peace and sustainable forms of development for all the communities encompassed with its given form. Such management can be accomplished by, for instance, cross-cultural education entailing dialogue, cross-cultural communication or joint educational initiatives, involving members of various communities of diverse cultures, faiths, nation, world's perspectives and geopolitical alliances. Predominantly, however, due to its multi-dimensional level, cultural diversity is best manageable if tackled through the framework of the abovementioned civil society, that lies at the foundation of NGOs activities and its core, overall objectives, i. e. human rights, democracy, economic and social capital growth, conflict prevention, and peace building.

If cultural diversity generates intolerant, hostile and aggressive activities aimed at such heterogeneous cultural reality, it can result in an extreme forms as an armed conflict. The war in Bosnia in the years 1992-1995 provided one of the most dramatic and ghastly examples of that kind. The spiral of hate initiated by the ethno-nationalistic political parties and their extreme right-wing media advocates during the collapse of Yugoslavia began to spin at the bewildering pace. The acts of ethnic cleansing became an objective for almost each of the involved sides, whereas the administrative form of inter-ethnic aggression was reflected in new constitutions of the former republics of Yugoslavia, that did not provide any protection for the national minorities. It was followed by acts of mutual extermination, wave of violence, fear, despair and the overwhelming tragedy of the civilians on all sides. The Bosnian conflict of a complex provenance, tackled the most intricate and trouble spots and issues of the religious, ethnic, national and linguistic identity. Thus, it permeated factors forming contemporary civilizations, and at the same time the culture.

It is one of the reasons cultural diversity is a subject of interest for number of international organizations and global legal and/or political structures, such as European Union or the United Nations. Organizations of that kind make the effort to undertake activities which could appease conflicts in the future or counteract them, supporting the idea of community, integrity and building compromise, counteracting hostility and resentments entailing historical animosities. The International Fund for Cultural Diversity (IFCD) sets one of the examples of such instruments. It accepts applications from parties, NGOs and INGOs for its funds seeking to promote cultural diversity. Unesco's ${ }^{1}$ International Fund for Cultural Diversity supports projects that aim to foster the emergence of a dynamic cultural sector, primarily by facilitating the

\footnotetext{
1 With regards to UNESCO recent activities in Bosnia-Herzegovina the project "Rebuilding together" can be recalled. UNESCO with some substantial support from the French government aim to rehabilitate cultural institutions in Bosnia and Herzegovina. As they puline sof the project implies "In a mark of solidarity, France donated 1 Million euro to support the reconstruction of 3 cultural institutions: Doboj,
} 
Introduction of new cultural policies and cultural industries, or strengthening the existing ones (Rashmi, retrieved online).

Acknowledging that cultural diversity encompasses a "mix of cultures based on religion, education, ethnicity, marital and family status, sexual orientation, and other unifying life experiences" (Saee, 2004) Bosnia-Herzegovina provides a very interesting example of a contemporary culturally diverse environment that was affected by an atrocious war, and therefore is now a place of intense activities of various domestic and international NGOs, that seek to find ways of cross-cultural cooperation and peaceful co-existence. As a historical meeting point for representatives of Ottoman and Muslim (a reminiscence of the almost five hundred-year long Turkish rule) cultures, as well as those of Balkan traditions, the Orthodox Church and Western European lifestyles, this intercultural society has created a crossroads for the West and the East. Such historically conditioned cross-cultural borderland established a point of reference for a culturally heterogeneous discourse, that allowed community members to enrich their cultural identities and biographies with unique aspects of the local, extraordinary culture inspired by the Orient and the Occident.

\section{Bosnian case study}

The challenge of reconstructing Bosnia linked to the of NGOs in this regard seems to be intrinsically corresponding to the process of overcoming the trauma of the war memories. Yet, as Ignatieff implies, "until the outbreak of hostilities, Bosnians possessed a variety of parallel identities [...] Differences in religion and ethnicity did exist, but they were, of a minor nature" (Ignatieff, 1998).

In Bosnia-Herzegovina there are many non-governmental and international organizations of different kind, accomplishing the task of empowering and supporting changes towards peaceful coexistence of the local, culturally diverse communities. The below examples reflect a selection of some of the most interesting and outstanding projects accomplished within the framework of civic, non-governmental activities, that contribute to the reconstruction, perseverance and promotion of the Bosnian cultural diversity.

\section{Dadalos}

Dadalos is a non-governmental organization of international reach carrying educational projects of the UNESCO agenda regarding civil education and democracy training. Educational coaches work voluntarily with the local youth within the following range:

human rights and examples of their famous advocates (such as Mahatma Ghandi, M. L. King, Mother Theresa);

democracy: its specificity, sources, definitions,the role of the opposition, essential freedoms

political parties: kinds and functions;

The European Union: history, institutions, and challenges.

Offering online learning and teaching materials the tackled themes concern for instance:

Human Rights,

Maglaj \& Bosanski Šamac. The project is not only a rebuilding challenge but also an opportunity to contribute to the full recovery and wellbeing of the population heavily affected by the floods through the re-establishment of essential cultural public services". The meeting hosted by the Institut français in Sarajevo will allow for an exchange of know-how and experiences around the question: "How does culture foster intercultural dialogue?". Bearing in mind the link between European integration and reconstruction, Sarajevo will be illustrated as a laboratory city in Europe with its cultural diversity and its post-conflict situation. The encounter will comprise a series of lectures, workshops and round tables to speak about deconstruction/reconstruction of European territories and to challenge participants to express concepts and ideas. A thematic in-the-field day "Reconstruction beyond rebuilding", with visits to Maglaj and Doboj, will close the event. 
Democracy,

Parties,

European Union,

Globalization,

Peace Pedagogy

United Nations,

Sustainability.

The resources are provided in English, German, Serbian, Bosnian, Albanian, Bulgarian, Croatian and Romanian.

Within the methodology of such activities, the courses provide various activating and didactic schemes, depending on the main subject group and always taking into account the four steps in preparing a lesson, i. e. adjustment to the topic, selection of the didactic perspective, formulation of the topic and planning the course of the lesson (or a workshop). Moreover, didactic principles help in preparing and giving politics lessons.

As far as the lessons in politics are concerned (see Chart 1) the topic embraces various level of analysing the dynamics of the democratic rules and its principles, starting from the grass-root level, i. e. at school, as reflected in, for instance, a class council. The methods, typically for NGOs modus operandi entail apart from fundamental didactic methods, activating techniques such as democratic-oriented debate, making projects or Betzavta method ${ }^{1}$.

In case of the other core topic for the cultural diversity management, i. e. education for peace (see Chart 2), the methodology regards the issues related to peace education such as fair play or preventing violence in sport, conflict management related to conflict analysis, manners of dealing with conflicts and its practical examples at schools, embracing the four main themes linked to this domain, i. e. war, peace, violence and conflict'2. It can be used by teachers, pedagogues, school councilors and all those working with the Bosnian youth, aiming at civil education or shaping attitudes of cross-cultural tolerance making reference to knowledge, appropriate attitudes, behaviours and positive emotions towards the representatives of a culturally diverse environments.

\section{The Institute for Strengthening Democracy in Bosnia And Herzegovina Democracy and Human Rights in Multiethnic Societies}

The founder of the Institute, professor Džemal Sokolović organized a series of international seminars "Democracy and Human Rights in Multiethnic Societies" which were run from 1998 with the participation of University of Bergen Norway, Fond Otvoreno drustvo (BiH), Institusjonen Fritt Ord (Oslo, Norway), Ministry of Foreign Affairs of Norway (Oslo), OSCE

\footnotetext{
${ }^{1}$ Betzavta is a Hebrew word and means "together". The title of this method of learning democracy, which was developed by the Adam Institute in Israel, makes up the programme and philosophical background at the same time. The Betzavta method includes a series of workshops, each workshop containing an interactive task or activity, followed by a reflection session afterwards. The goal of the interactive task is for people to delve into their natural patterns and behaviours, while the reflection session afterwards gives an opportunity to reflect on that behaviour. http://www.mellemeducation.org/betzavta-method/

2 Some other examples coming from Bosnian area of the NGOs activities concern the VESTA NGO, which in 2015 cooperating with the Office of the EU Special Representative, on account of the "EU and YOU" initiative made it possible for 17 students from BosniaHerzegovina travel to Brussels as the winners of the EU Debate Competition held in Sarajevo, on June 3-4, 2015. Students were from the University of Mostar, University of Bihac, University of Banja Luka, University Džemal Bijedić in Mostar, University of Sarajevo, University of Tuzla, University of Zenica, University of East Sarajevo with the Medical Faculty of Foča, the University Centre in Bijeljina, the Faculty of Economics Brčko and International Burch University. http://www.vesta.ba/en It is worth to notice that the team of VESTA launched the project "Outreach to Undergraduate Students in BiH" with the theme "EU and YOU", under the auspices of the Office of the EU Special Representative in $\mathrm{BiH}$.
} 
Mission to Bosnia Sarajevo (B\&H), Sund commune (Norway), Konjic municipality (B\&H), Nansenskolen (Lillehammer Norway), Norwegian Helsinki Committee Oslo, and many others. It is worth to stress the fact that these seminars were organized with indeed active participation of the local communities, whose members worked at the organization, hosted the guest coming from various international academic centers, run the administrative office and helped with other crucial arrangements. The seminar held every year until 2006 were only one of the various forms of activating the local and global communities to contribute to the discourse of Bosnian cultural diversity.

The Institute's mission established by its founder, Dz. Sokolović, is as follows:

1. "Preservation of Bosnia-Herzegovina Social Science - The principal tasks of the Institute may not be accomplished if one does not biologically and intellectually preserve Bosnian social science and Bosnian social scientists. Social scientists from Bosnia-Herzegovina must be included in the scientific life and research activities in Europe. Those who have already fled from Sarajevo should assemble somewhere in Europe where they find support for this enterprise. Those remaining in Bosnia-Herzegovina must receive research support and can be included in the research projects of the Institute.

2. Encouragement of research projects, publication of books and articles in scientific journals, and workshops and conferences concerning Bosnia and topics related to the Bosnian war and post-war reality.

3. The think-tank group for Bosnia-Herzegovina - A group of experts, consisting of Bosnian and other scientists from different social science fields, will be at the disposal of governments with special interest in Bosnia-Herzegovina as well as to institutions of the international community. In addition, the group will regularly inform the public (the mass media particularly) about the situation in Bosnia-Herzegovina and seek support for political initiatives.

4. The Institute will cooperate with all institutions of the international community such as the UN and EU, as well as all scientific institutions dealing with the case of Bosnia, researching war and peace issues, and inter-ethnic relations.

5. The Institute's services will be at the disposal of all international organizations dealing with the problem of Bosnia, particularly those interested in human rights, peace, the improvement of democratic institutions, and those dealing with humanitarian relief and the post-war cultural, social, political and economic restoration of Bosnia-Herzegovina.

6. The Institute will aid the government of Bosnia-Herzegovina as well, so that it helps in the search for a democratic and peaceful solution and acts to preserve the integrity of Bosnia-Herzegovina and the restoration of a civil society.

7. If the international community sets up an UN protectorate over Bosnia-Herzegovina or the EU establishes its own administration in Sarajevo and other cities, the Institute will participate as an expert consulting body" (Institute for Strengthening Democracy in Bosnia And Herzegovina Democracy and Human Rights in Multiethnic Societies, retrieved online).

With regards to objectives oriented toward such priorities, the aims of the Institute are designed to be achieved through the following forms of activity:

Research - theoretical and empirical;

Teaching - workshops, seminars, conferences, lectures, instruction for professionals (UN employees, journalists, etc. );

Education - preparing the citizens of Bosnia-Herzegovina for future democratic life and political participation;

Publications and acting through the mass-media;

Information-documentation centre and library; information campaign in the mass media.

Being aware of the fact that it is of crucial significance for a society's moral renewal to have all criminals punished, but even more crucial than that is to keep the memory of those who have done good, Sokolović, a former researcher at the University 
of Bergen in Norway, established within the framework of the Institute for Strengthening Democracy in Bosnia And Herzegovina Democracy and Human Rights in Multiethnic Societies a unique archive of "good deeds" ("Researching the Good"), made during the war in Bosnia.

The project consisted of two parts: 1) A research project directed and carried out by the scholar on "Researching the Good in Bosnia and Prospects for Reconciliation"; 2) Education and teaching activities.

The idea sparked in Sokolović's mind as early as during the first days of the war in 1992. As a member of a multicultural environment he was convinced that the shared years of mutual integration, cooperation and co-existence can also bore fruit of kindness and heroism under such dramatic circumstances. As a former citizen of Sarajevo, he recalls that this city comprises of a multiethnic community: "in the building where I lived all nationalities lived together, one next to another. During the war and the siege we could not leave this place, so we had to cooperate to get fresh water or food. Outside they were fighting against each other, inside- we were helping each other"1.

The aim of the first part of the project was to recognize, record, file and release information (testimonies) on the acts of "the good" across ethnic/religious lines having occurred during the Bosnian war. The collected data concerned the period 199295. The project's objective was to set up a data base recording the cases in which Bosniaks, Croats and Serbs were supporting, helping, and protecting each other, and even risking or sacrificing their lives in order to counter the evils of ethnic hatred, violence and war, and to incite and spur good deeds.

The aim of the second project was to develop co-operation in teaching and research between Department of Comparative Politics, University of Bergen, and institutions of higher education and research in the Balkan region through workshops, conferences, and exchange of staff and students. Cooperative links have been established with University of Sarajevo, University of Belgrade, University of Zagreb, Institute for Strengthening of Democracy in Bosnia, and other institutions in the region were invited to take part in joint activities (The Politics of Democratic and Welfare Development in South Eastern Europe: A Network for Research and Education, retrieved online). Coordinator of the project in Bosnia, Sevla Krivić, was working locally in the field (Konjic) in the mid 2000s archiving statements and memories of each of those, who against nationalist propaganda of violence and hatred in view of ethnic and religious differences, protected and saved their "culturally" (i. e. religiously or ethnically) diverse neighbours, friends or work colleagues from the hostilities of war, driven by their sense of humanism and consciousness. The research reports were written on the basis of the collected data. The archive contains over 300 of such stories.

Collecting the testimonies of all the noble, loyal and heroic cross-cultural gestures was not an easy nor a safe task. Some of the team members gathering the recollections were objects of attack and threats on the ground of the idea they were to accomplish by such design, i. e. to prove that inter-ethnic bonds existed despite the madness of nationalism and ethnocentric propaganda. Notwithstanding, majority of the witnesses were willing to share their stories which were a moving, shocking and unforgettable record.

It proves that despite the propaganda of ethno-nationalists, Bosnia-Herzegovina is not a country of nationalists of separatist aspiration, but predominately a place of those, who for decades had been working out a common language of communication, cooperation and dialogue. Those were the ones making such dramatic decisions to fight for the lives of their neighbours or friends, although the conflict itself underestimated and severely affected these cross-cultural communities. The cross-cultural bond was also reflected in the team of persons working for this project. The two main coordinators from Konjic are women - Sevla Krivić, a Mulism, and Vesna Saradžić - a Bosnian Serb (they worked in an office with a big poster on the wall saying "who shall we blame?"). The three-year long project was a part of a bigger scheme concerning democracy and social welfare within the framework of the Institute of International Affairs at the University of Bergen and some higher education units in Bosnia-Herzegovina. The efforts made to finalize the project researching the Good in Bosnia and Prospects for Reconciliations were crowned with a documentary made by Sokolovic "And there was light". All of the gathered stories prove that compassion, respect and recognition of the human dignity regardless of the

\footnotetext{
1 From an interview made by the author with Dz. Sokolvić in autumn 2015.
} 
faith, ethnicity, nationality or any other background is the fundamental premise acknowledging human solidarity and a peaceful coexistence.

\section{Pontanima Choir}

The unique Pontanima Interreligious Choir provides another interesting example of centrifugal activities of a grass-root and civic nature, acting as one of the most important actors in the field of inter-religious peacemaking in $\mathrm{BiH}$, and responding to some key concepts of cross-cultural education, interreligious dialogue and human solidarity. The choir proves that religions can also function as a joint planes of agreement, contact and communication not only division (as it is commonly acknowledged by scholars, cf. Ramet, 1988). Thus in such context diversity is cultivated as a source of healing, hope and celebration. The concept and accomplishment of the choir's cross-cultural goal contribution to the pace making is reflected in the following awards:

Peace Award from Tanenbaum Center for Interreligious Understanding (1998)

\section{Common Ground Award from Search for Common Ground (2004)}

City of Sarajevo honored the choir for its contribution to the arts, building a culture of peace and promoting the cultural heritage of $\mathrm{BiH}(2006)$

\section{Pax Christi Award for 2011.}

Established by Ivo Markovic, a priest and scholar in 1996, i. e. shortly after the war in Bosnia, the interfaith Pontanima choir from Sarajevo was to be "a form of positive provocation (...) We wanted to show these religious groups, so fully enslaved to nationalism, that there is another way to be, that religions can make positive contributions" (Ivo Markovic's Profile, retrieved online). Another member of the choir, a conductor and an opera singer, Josip Katavić, says "(...) dialogue?... If I ceased to believe in the possibility of understanding I would have to leave this place instantly. Only faith keeps me still in Bosnia (Pontanima, most dusz, retrieved online). The choir's activities provide artistic, yet spiritual and truly socially activating form of to cooperative, open, constructive and positive interaction between people in a culturally diverse context.

Pontanima's music reflects the beauty of a artistic diversity that originating from a complex, religiously diverse background and shows that religious can be used not only as a tool of ethno-nationalistic forces to fuel conflicts, but can send a clear message that the centuries-old tradition of religious co-existence and cooperation of Catholics, Orthodox Christians, Muslims and Jews in Bosnia and Herzegovina fosters the unique Bosnian identity that is based on the richness of diversity.

It should be stressed, however, that not all examples paint such a rosy outlook. For instance, Polska Akcja Humanitarna (Polish Humanitarian Action) ${ }^{1}$ a Polish non-governmental organization was also a part of the empowering efforts undertaken after the war in Bosnia in the 1990s. In 1998 PAH was planning to rebuild a primary school Osman Nuri Hadžic in Dobrinja, in the in the eastern outskirts of Sarajevo. The decision was already made in December 1996, when PAH established a Committee for the reconstruction of the school on Sarajevo, inviting to this project some prominent public figures such as former Polish Prime Minister and a Special Rapporteur of the Commission on Human Rights, Tadeusz Mazowiecki. Unfortunately in 1997, due to the fact the area of school was overtaken by the Bosnian Serbs, the place became again a spot of a conflict hence the decision was made to carry out the reconstruction works for some other school in a location indicated by the local authorities (Raport z działalności Fundacji Polska Akcja Humanitarna za rok 1998, retrieved online).

It proves that resentments might still be strong part of the social discourse and may significantly hinder the activities of

\footnotetext{
${ }^{1}$ The mission of PAH is "to make the world a better place by alleviating human suffering and promoting humanitarian values. We understand responsibility for the world as the possibility for each PAH employee and volunteer to actually participate in the aid process and influence it. The work of any of us contributes to saving people's lives. This obliges us to develop ourselves and to raise the quality of our aid". Retrieved from http://www.pah.org.pl/o-pah/71, 2016, February 13.
} 
various NGOs, hence they should be counterbalanced by dynamic and effective education projects and other peacebuilding (or reconstructing) schemes.

\section{Conclusions}

Cultural diversity is a phenomenon that entails enormous social capital, richness of traditions, customs and lifestyle patterns, yet concurrently entailing some key challenges such as the threat of ethnocentrism, cultural discrimination, prejudices or exclusion. Multiculturalism is becoming a global issue due to number of geopolitical, social and even economic or technological reasons, hence it concerns all the human communities, that sooner or later will face the encounter with the Other. It is not possible to foresee the course such encounters will take, nonetheless there are many ways to prevent from a hostile, violent or prejudicial character of such experiences. Carried out by various NGOs, educational projects run within, for and with the crucial participation of the local community members, serve as a tool of a constructive management of the cultural diversity.

As the example of former Yugoslavia and Bosnian wars prove, cultural diversity is a factor that can strengthen, or quite the contrary - question and undermine the cross-cultural environment and its peaceful existence. The recalled examples of domestic NGOs and other educational, academic or artistic projects prove the civic engagements, grass-root involvement and innovative approach to education can assist in the process of strengthening the fragile structure of cultural diversity that is often subject to various political (global or local) manipulation and ethno-nationalistic schemes.

It is of paramount importance to allow the local communities to take responsibility for their actions in terms of the closest social and cultural surrounding, to get personally involved in the cross-cultural dialogue, and to adopt an active approach to the social, political and cultural discourse. If such communities are, or have been, affected by an armed conflict an internal assistance in restoring the social and political deal should be applied, however, as the examples of some Bosnian NGOs prove, the best and most effective results of a positive change can be expected when the activities are not imposed top-down but evolve at grass-roots level. They can adopt a form of educational and research projects engaging the members of the local communities or some selected groups, as for examples artists or scholars showing with their attitude that inter-religious dialogue is a capital that can serve as a foundation for further peace-building and reconstructing practices.

Moreover, the Bosnian selected case studies in this range prove that it does not require a substantial financial aid to run an effective, local-oriented project, as it is more the matter of a good will, enthusiasm and openness of mind of those living in a culturally diverse community. By doing so, intercultural skills are empowered, facilitating curiosity and openness, as well as a readiness to suspend disbelief (or prejudices) about other cultures, the ability to acquire new knowledge concerning other cultures and cultural practices or customs, and to use that knowledge in real-time communication and interaction with members of culturally diverse environments, demonstrating cultural sensitivity and empathy.

\section{References}

[1] Betzavta method. (2016, February 11). Retrieved from http://www. mellemeducation. org/betzavta-method/

[2] Burri-Nenova, M. (2009). The Protection and Promotion of Cultural Diversity at the International Level. Cultural Diversity: Issues, Challenges and Perspectives, Nova Science Publishers, New York.

[3] Commission Report to the European Parliament, the Council, the European Economic and Social Committee and the Committee of the Regions on the Implementation of the European Agenda for Culture. COM/2010/0390. (2016, February 13). Retrieved from http://eur-lex. europa. eu/legalcontent/EN/TXT/?uri=celex\%3A52010DC0390

[4] Convention on the Protection and Promotion of the Diversity of Cultural Expressions 2005 (2016, February 10). Retrieved from http://portal. unesco. org/en/ev. phpURL_ID=31038\&URL_DO=DO_TOPIC\&URL_SECTION=201. html

[5] Definition of NGOs (Retrived 2016, February 13). Retrieved from http://www. ngo. org/ngoinfo/define. html 
[6] Fromm, E. (2011). Escape from freedom, Ishi Press, Edinburgh.

[7] Ignatieff, M. (1998). The Warrior's Honor: Ethnic War and the Modern Conscience, Random House, London.

[8] Institute for Strengthening Democracy in Bosnia And Herzegovina

Democracy and Human Rights in Multiethnic Societies. (2016, February 12). Retrieved from http://isd-bh. org/?page=about

[9] International Convention on the Elimination of All Forms of Racial Discrimination

[10] Ivo Markovic's Profile. (2016, February 11). Retrieved from http://www. beyondintractability. org/profile/ivomarkovic

[11] Political/Military Background of ALTHEA (2016, February 12). Retrieved from http://www. euforbih. org/index. php?option=com_content\&view=article\&id=2821.

[12] Polska Akcja Humanitarna. About Us. (2016, February 12). Retrieved from http://www. pah. org. pl/o-pah/71

[13] Pontanima, most dusz. (2016, February 11). Retrieved from https://www. tygodnikpowszechny. pl/pontanimamost-dusz-17179

[14] Project Cycle Management Training Programme Report. (2016, February 11). Retrieved from http://www. vesta. balen

[15] The Politics of Democratic and Welfare Development in South Eastern Europe: A Network for Research and Education. (2016, February 13). Retrieved from http://uni. no/nb/uni-rokkansenteret/the-politics-of-democraticand-welfare-development-in-south-eastern-europe-a-network-for-research-a/

[16] Putnam, R. D. (1995). Demokracja w działaniu. Tradycje obywatelskie we współczesnych Włoszech, Wydawnictwo Znak, Kraków-Warszawa.

[17] Rabczuk, W. (2002). Educational policies of European Union for Immigrants, and Ethnic and National Minorities (in Polish) IBE, Warszawa.

[18] Ramet, P. (1988). Religion and Nationalism in Soviet and East European Politics, Duke University Press Books, Durham.

[19] Ramet, S. (2005). Thinking about Yugoslavia : scholarly debates about the Yugoslav breakup and the wars in Bosnia and Kosovo, Cambridge University Press, Cambridge.

[20] Rashmi, K. International Fund for Cultural Diversity to Parties/NGOs/INGOs to Strengthen and Promote Cultural Policies \& Industries in Developing Countries (2016, February 11). Retrieved from https://www. fundsforngos. org/culture-2/international-fund-for-cultural-diversity-partiesngosingos-strengthen-promotecultural-policies-industries-developing-countries/

[21] Raport z działalności Fundacji Polska Akcja Humanitarna za rok 1998. (2016, February 12). Retrieved from

[22] http://www. pah. org. pl/m/309/Raport_98. pdf

[23] Saee, J. (2004). Managing Organisations in a Global Economy: An Intercultural Perspective, 1st ed., SouthWestern College Pub.

[24] United Nations Treaty Collection. Convention on the Rights of the Child.

[25] United Nations Treaty Collection: Convention against Torture and Other Cruel, Inhuman or Degrading Treatment or Punishment.

Chart 1: Selected methods for given subject groups within the framework of the international UNESCO education server D@dalos dedicated to democratic education through "lessons in politics". 


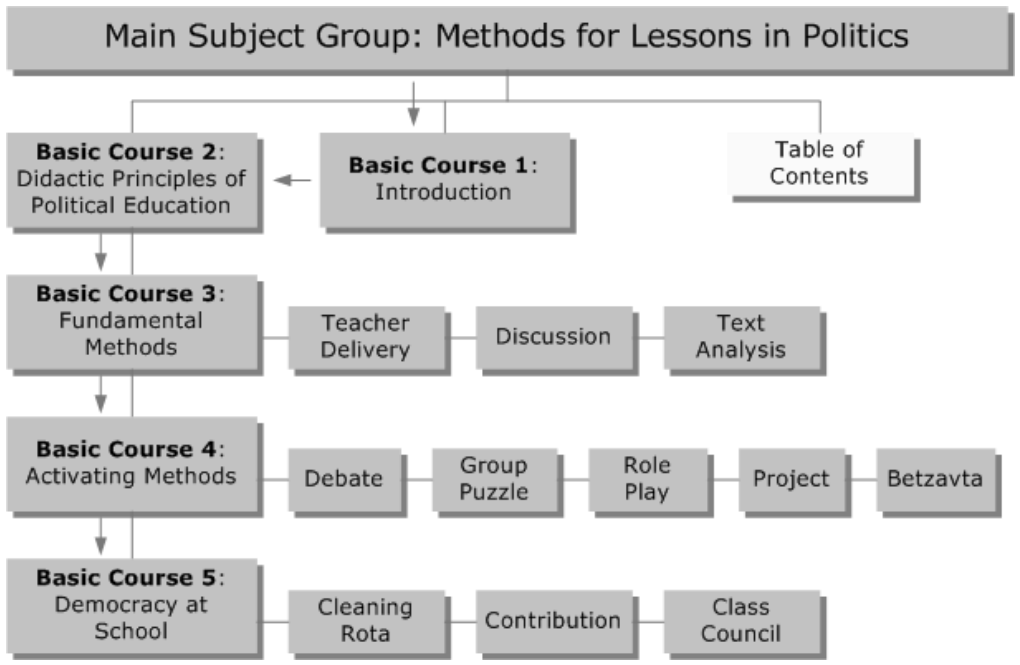

Source: http://www. dadalos. org/methoden_int/uebersicht. htm. Retrieved 2016, February 10.

Chart 2: Selected methods for given subject groups within the framework of the international UNESCO education server $\mathrm{D} @$ dalos dedicated to civic and peace education.

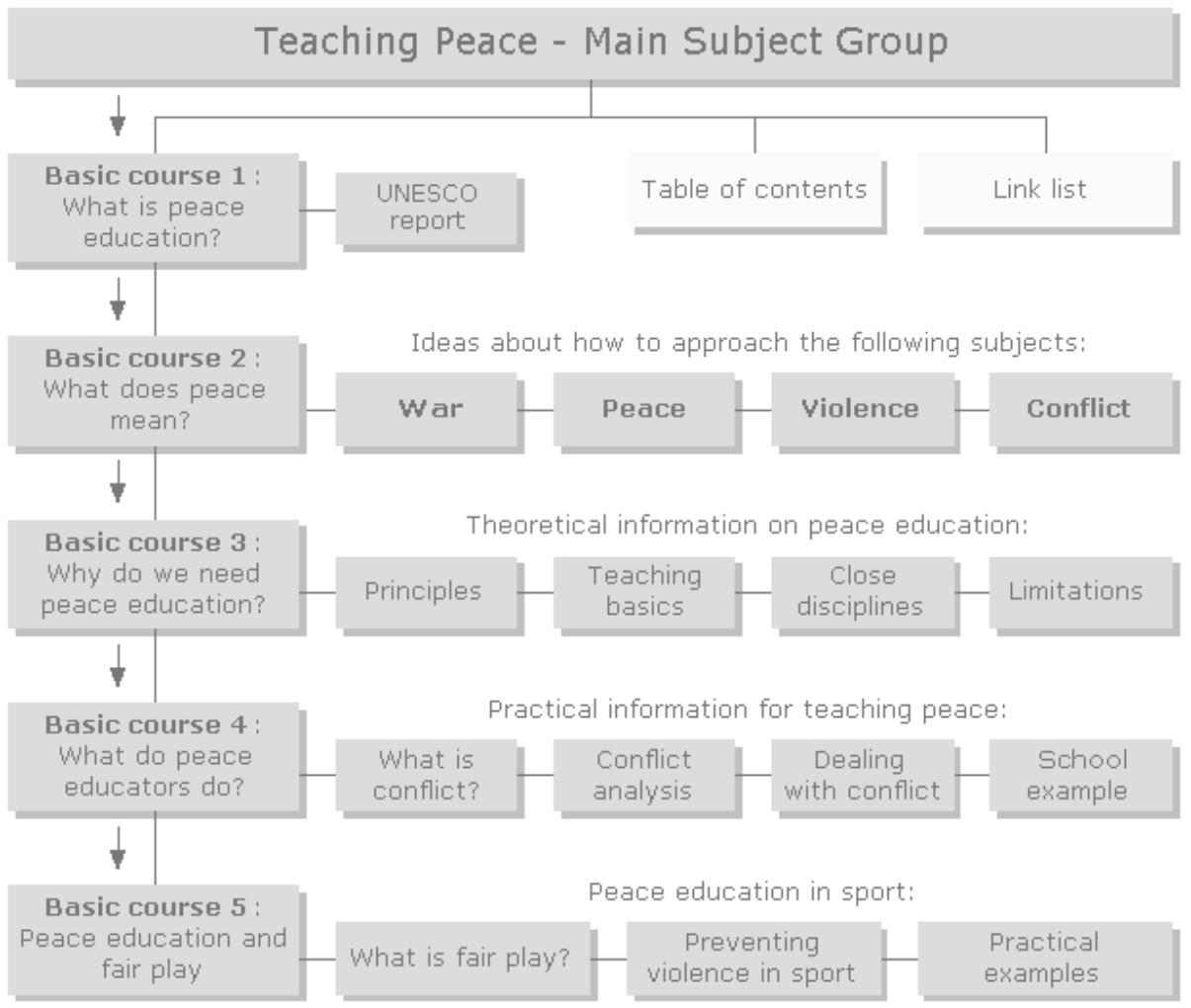


Source: http://www. dadalos. org/frieden_int/uebersicht. htm. Retrieved 2016, February 12. 